\title{
Students' Syntax Error In Writing Ability
}

\section{Rulik Setiani ${ }^{1}$ \\ Program Studi Pendidikan Bahasa Inggris STKIP Muhammadiyah Kotabumi}

\begin{abstract}
Abstrak
Writing is one of the language skills that must be mastered by students. By writing students can pour their ideas, opinions, and thoughts in writing. However, there are still some students who make mistakes in writing activities, especially writing English text. errors that are often done by students in writing English text is a misuse of syntax that is divided into errors in phrases, clauses, and sentences.
\end{abstract}

Keywords: Syntax, Error, Writing Ability

\section{Introduction}

Writing is the important skill that must be mastered by language learner, because writing can be used to give explanation and opinion in written form. To write appropriately, it is needed students' mastery of other English components. The students should master grammar, vocabulary, and punctuation. They must be able to organize the ideas to construct the sentences appropriately. Beside that, in writing, a writer should interpret his or her thought into language which can be understood by the readers without any further help from the writer. It is clear that writing is much more than arranging the word into a paper, it also requires ideas that should be transferred into written from that make it become concrete and visible to write well, so that the readers can explore what they have read. Besides, to write well the students are expected to be able to present their ideas in written well.

Writing is complex skill than other language skills, it is because if the students do not master writing, it make the students difficult to learn another skill. Writing can be manifestations of utilization of language as a media of communication, and it is one of the crucial ways to deliver information through a language which is mastered by people. By mastering writing, it also shows how someone masters the language well. It is because writing is complex skill which needs many components of language. The language components need in writing are organization, content, grammar, vocabulary, and mechanic. In addition, writing is not as simple way. It needs also to have something important to be written and it must be arranged correctly, so the one who reads will understand it's written. 
In order to have sufficient skill in writing, it is not easy. The process of teaching and learning writing is complex and quite difficult. In the teaching process, the teacher should use appropriate materials, such as appropriate text. In deciding appropriate text is also not easy. The teacher needs to consider the learners' knowledge level, characteristic, etc. The fact, the ability of their writing is still poor, many students still have dificulties in writing English, they often do error in their writing, those errors can be in phrases, clauses, or sentences.

\section{Discussion}

\subsection{Writing Ability}

Writing was difficult ability that must be mastered by learner, because writing ability was more grammatically and also lexically complex than other language skill. Accuracy was need to deliver and compose the idea in writing, also the punctuation was important to be mastered in making the best written. Those cased were usually made the students were lazy to write something or did the task which given by their teacher. Beside, writing was complex ability in expression idea, thought, and feeling of the writer in the written form. Thought the processes of writing, there would be a communication between them. In this case, writing was one of the language skill which deal with the ability of arranging of the text in making a text, in order that the reader could understand the message or information contained in a text.

According to Harmer (2004:31), writing is one of the four skill of listening, speaking, reading, and writing has formed part of the syllabus in the teaching of English. However, it can be used for a variety of purpose, ranging from being merely a 'backup' for grammar teaching to a major syllabus strand in its own right, where mastering the ability to write effectively is seen as a key objective for learners. Meanwhile, Tarigan (2008:3) states that writing is a language skill that is used for indirect communication. The students can communicate their ideas through written form such as letter and message for communication. From this statement, it can be inferred that writing refers to a process in which its activities are not produce immediately.

In addition, writing is very closely related to the ability. Learners can be said to have ability if someone can do something well. According to Hornby (2003:2) ability is skill or power required to do something. It means that ability is activity to do something which is need competence, skill to overcome with a problem. According to Miller and William (2011:11) ability is talent. It can be 
assumed that ability is something capability to do, use or apply something well.

Based on the statement above, it can be concluded that writing ability is someone's capability to express his or her ideas into written form correctly as a means of communication as well.

\subsection{Teaching Writing}

Teaching writing is communicative process which uses conventional graphic system to convey a message to reader or receiver. It means writing is communication between the reader and the writer. A good writer is if someone clearly writes what he or she thought of to the reader. A good reader is if someone can understand what they read. If it is happened, it is clear that the purpose of writing and reading process have been achieved. However, to achieve the purpose of writing is not easy. Writing ability is highly complex. It takes study and practice to develop this skill. For both native speaker and new learner of English, it is important to realize that a piece of writing always needs to be revised and reviewed. There are four main stages in teaching writing process: prewriting, planning, writing and revising drafts, and final writing (Oshima, 1991:3-12). The stages are described as follows.
1. Pre writing

The first stage is planning (prewriting). Prewriting is the stage where to generate ideas for what to be written. The following activities provide the learning experiences for students at these stages:

a. Brainstorming

Brainstorming is the prewriting step to generate ideas. Many teachers and learners seem that this activity is unnecessary at first, after doing them a few times, they will realize their usefulness. Brainstorm for ideas can get students writing is more quickly and give more time to the next stages of writing.

b. Listing

Listing is brainstorming technique in which the students think about the writing topic and quickly make a list of whatever words or phrases come into their mind. The teacher may guide the students to produce as many ideas as possible in a short time, and find specific focus for the topic.

c. Freewriting

Freewriting is a brainstorming activity in which the students write freely about the topic. While the students are writing, another idea will come. As with listing, the purpose of freewriting is to 
generate as many ideas as possible and to write them down without worrying about appropriateness, grammar, vocabulary, content, mechanics, and organization. The students can continue freewriting as long as he or she can generate ideas related to the topic. Then, after completing that task, the students can reread it and develop certain points, add some more ideas, or even delete others. The student can do this freewriting activity several times until they are satisfied what they have written.

d. Clustering is another brainstorming activity can be used to generate ideas. The students may write the writing topic in the center of paper and draw a circle around it. Then, write every idea comes into the circle around the core. Think it again, and make more circles of ideas around them.

\section{Planning}

The second stage is planning. In this stage, the students are guided to choose topics and narrowed them, and the students generate their ides by brainstorming. The students are guided to organize the ideas have been generated by brainstorming into an outline.
The first step toward making an outline is to divide the ideas in the list further into sub lists and cross out any items that do not belong or that are not useable. The second step is writing the topic sentence. Finally, the students can write a topic sentence. The topic sentence is the most general sentence in a paragraph, and it expresses the central focus of the paragraph. The third step is writing outline. In outline, the students write down the main points and sub points in the order in which they play to write about of. By doing these three steps, writers are expected to produce writing that will be able to explain something to the readers.

3. Writing and Revising Drafts

The third stage is writing and revising drafts. In this stage, the students are guided to write and revise several drafts until they have final writing. The steps of this stage are writing the first rough draft from the outline, revising the content and organization, proof reading the second draft to check of grammar, sentence structure, spelling, punctuation, and vocabulary.

\section{Final Writing}

After passed the three previous stages, the students have finished their writing task. They have their final 
writing. The teacher will expect to be written neatly and legibly. The students must be sure that they make all the corrections that they noted on their draft.

From the explanation above, it can be concluded that in teaching writing is not only focuses on the grammatical form, also focuses on the process to guide the students to express and develop students' ideas in arranging sentences. The students should express themselves in practicing their skill by following the four stages of teaching writing.

\subsection{Concept of Errors}

In order to analyze learners' errors in learning a foreign language, it is crucial to make a distinction between errors and mistake. According to James (1998:78), there is difference between mistakes and errors, if the learner is inclined and able to correct a fault in his or her output, it is assumed that the form he or she selected was not the one intended so that the fault is a mistake. If the learner is unable or in any way disinclined to make the correction, it can be assumed that the form the learner used was the one intended that it is error.

The definition above is supported by Edge (1989: 11) who states that mistake is term being wrong for foreign language learners that corresponding to their wrong. Errors are forms that the pupil could not correct even if their wrongness were to be pointed out.

From all explanation presented previously, the writer draws a conclusion that error and mistake is different. Errors are ungrammatical sentence which refer to the language competence and mistake are imperfectness of sentence which refer to the language performance. Mistakes can be corrected by the students and error cannot be corrected by the students.

According to Nurgiantoro in Setiadi (1997:26) states point of view, analysis of error is reffering to the analysis of activity generated by students' languge error, such as finding, identifying, describing, calculating, and determining the sources of error frequency.

\subsection{Concept of Syntax}

Error analysis is the way to know about students' error which is to collect, to identify and to classify the kinds of error. In classifying grammar error, there are two error namely morphology error and syntax error. Morphology error is the error that describes the formation of words, and syntax error is the error that describes the construction of meaningful phrases, clauses, and sentences out of words, but this atrticle focuses on syntax error based on phrases, clauses, and sentences of students' writing ability. 
Brosley in Kurniati (2002:9) states that the syntactic theory is concerned with the way words are combined to form sentences. Syntax may be roughly defined as the principles of arrangement of the construction formed by the process of derivation and inflection (word) into larger constructions of various kinds.

Syntax is the study of the principles and processes by which sentences are constructed in particular languages. In linguistics, the study of the rules that govern the ways in which words combine to form phrases, clauses, and sentences. Syntax is one of the major components of grammar. The arrangement of words in a sentence. There are errors that effect texts larger than the word, namely phrase, clause, and sentence. Those are the syntax error, the detail syntax error will be explained as follows:

\section{a) Phrase}

Phrase is grammatical unit which is smaller than a clause. According to Muntaha (2009: 63) phrase is a group of words that make some sense, but not complete sense since it has no subject, predicate and it is not sectioned a sentence. For instance: 'in the middle of the night', it makes some sense but it does not have complete sentence. Hariyono (2003: 17) says that phrase is a group of word that has one meaning, and phrase is a part of sentence. In English grammar phrase devided into four.

1. Noun Phrase

Noun phrase is phrase that has function as noun, and as subject or object in one sentence. Example :

a) The students do their task.

b) They are students of English department.

On italic word, that is the noun phrase the example above (a) the students is noun phrase as subject and (b) students as object.

2. Verb Phrase

Verb Phrase is consisting with auxiliary and verb that make form tense. Example:

a) she can swim

b) he was caused broken heart

The example (a) and (b) on italic word Can swim and was caused is verb phrase form tense.

3. Adjective Phrase

Adjective phrase is phrase that has function like adjective, and explains a noun. Example:

a) Marry is very happy with her work

b) The girl with the curly hair is my sister

On the example (a) very happy is adjective phrase as adjective to explain a noun that is 'Marry', and (b) the curly hair is adjective phrase as adjective to explain a noun 'The girl'. 
4. Adverb Phrase

Adverb phrase is phrase that has fuction as adverb on verb. Example:

a) He swims in the small river

b) His move is very quickly

The example above on italic word (a) and (b) are adverb phrase, (a) ...in the small river is the adverb phrase that has function as adverb on verb 'swim' and (b) ...is very quickly is the adverb phrase that has function as adverb on verb 'move'.

\section{b) Clause}

According to Oshima (1991: 154), Clause is the building blocks of sentences. A clausa is a group of words that contains (at least) a subject and a verb. The clause is a traditional and fundamental unit of sentence structure, though the term is not used by all grammarians in exactly in the same way. Traditionally, a clause is a grammatical unit consisting of a subject and predicate, and every sentence must consist of one or more clauses. There are two kinds of clauses: independent clause and dependent clause, (Oshima 1991:154). Namely:

1. Main Clause (Independent clause)

A main clause or independent clause contains a subject and a verb, and it expresses

a complete thought. It can stand alone as a sentence by it self. Every main clause will follow this pattern: subject + verb + complement. Look at the following example:

a) Many lazy students whine in the class.

b) My dog loves pizza crusts.

The example (a) and (b) are main clause that can stand alone, on the example (a) many lazy students (subject) whine (verb) in the class (complement), (b) My dog (subject) loves (verb) pizza curts (complement). The important point to remember is that every sentence must have at least one main clause.

2. Subordinate Clause (Dependent clause)

A independent clause begins with a subordinator such as when, while, who, whose, if, that etc, followed by a subject, verb and complement. It does not express a complete thought and cannot stand by itself as a sentence. For example:

a) ..... if you leave your boyfriend

b) $\mathrm{He}$ is the man whose son was died yesterday.

The example above (a) and (b) on italic word are subordinate clause, and cannot stand alone. The subordinator there are 'if' and 'whose' after that followed subject, verb and complement.

Notice that subordinate clause begin with subordinator. The important point to remember about subordinate clauses is that they can never stand alone 
as complete sentences. To complete the thought, you must attach each subordinate clause to a main clause.

There are three kinds of dependent clauses: adjective, noun, and adverb. Each kinds is punctuated differently.

Relative Clause or Adjective
Clause

A relative or adjective clause is dependent clause introduced by relative pronoun or relative adverb. It function as an adjective, it modifies or describes a noun or pronoun in the independent clause. A relative clause will begin with a relative pronoun such as who, whom, whose, which, or that + noun. Relative adverb like; when, where, or why. Example :

- The lazy student whom Mrs. Russell hits in the head with a chalk eraser

- The university where I study English with my friend.

On italic word is relative clause (adjective clause). lazy student whom..., 'whom' there to describe or give information about 'lazy student'. University where..., 'where' it show the place that is 'university'. Like subordinate clauses, relative clauses cannot stand alone as complete sentences. You must connect them to main clauses to finish the thought.

b) Noun Clause
A noun clause is a dependent clause that has function as a noun. It can be a subject, object, or subject complement. However, in this research will study the noun clause only it is used as an object. Because a noun clause is dependent, it must be connected to an independent clause to form a complex sentence. A noun clause is used as an object is preceded by an independent clause called an introductory clause. The noun clause is the object of the introductory clause verb. There are three types of dependent noun clause : That clauses are made from statements, (that). Wh-question clauses are made from whquestion, (who, where, how). and yes/no question clauses are made from yes/no question, (whether, if).

The pattern is (Subject + verb + Object).

But Wh-question different pattern is (Subject subordinator + verb + complement).

Example :

- I know that people have different opinions about capital punishment

- Can you remember who made the error

- I do not know whether our homeworks are finished today

The example above, are the noun clause.

On the first example ' I know' (introductory clause) that people have different opinions about capital 
punishment (noun clause as object). The second example 'can you remember' (introductory clause), who made the error (noun clause Wh-question). And the third example 'I do not know' ( introductory clause), whether our homework are finish today (Yes/no question clause).

c) Adverbial Clause

An adverbial clause is a dependent clause introduced by an adverbial subordinato it is use to modify the verb of the independent clause and tell when (time), where (place), why (reason), for what purpose, how, how long, and how far. It is also use to show contrast and concession. The adverbial clause pattern is formed with:

( Subordinator + subject + verb + complement ) looking for example:

- Most people prefer to shop where they can be sure of quality

- People were eating a lot of protein while they were living on farms.

On the italic word in the example above are adverbial phrase, that use to modify the verb of the independent clause (most people prefer to shop) and (people were eating a lot of protein).

A clause is a part of a sentence. Each clause has only one main verb. I love you is a sentence which has only one clause. I love you and I will always love you is a sentence which has two clauses. The two clauses are I love you and I will always love you. These clauses are joined together by the word and (a conjunction). Two clauses can be joined with a pronoun. For example: I live in London, which is in England. Here, I live in London is the first clause, and which is in England is the second clause. The word which is a pronoun which takes the place of London. It joins the two clauses. A sentence can contain many clauses. But sentences with fewer clauses are easier to understand.

\section{c) Sentence}

Oshima (1991:155) stated that sentence is the largest linguistics unit which is held together by rigid grammatical rules. Sentence is a group that has at least one subject and one predicate that contain perfect meaning (Muntaha, 2009:110).

A sentence has function: a) to make statement; as "He is a clever student", b) to ask question; as, "Is he clever student?", c) to give commands; as, "please, Sit down!", d) to make an exclamation as, "What a nice day it is!". To name the part of sentence in English it consist of Subject (S) and Predicate $(\mathrm{P})$.

There are basically four kinds of sentences in English: simple sentence, compound sentence, complex sentence, compound-complex sentence. The kind of 
sentence is determined by the kinds of clauses used to form it.

1. Simple Sentence

A simple sentence is sentence that contains one independent clause:

a) My brother goes to England

b) I enjoy studying English at home

Those sentences just contain of one subject and predicate.

\section{Compound Sentence}

A compound sentence consists of two or more independent clauses joined together. Each clause is equal importance and could stand alone. There are three ways to join independent clauses to form a compound sentence.

- With a coordinator : I enjoy playing game, but I hate playing computer

- With a cunjuctive adverb: I enjoy playing game, however I hate playing computer

- With a semicolon : I enjoy playing game; I hate playing computer

Compound sentence can be formed with : (Independent clause, + coordinator + Independent clause).

In compound sentence, there is comma after the first independent clause. In copmpound sentence, there are only seven coordinators namely, for, and, nor, but, or, yet, and so. Which can be remembered by observasion FAN BOYS.

The independent clauses of compound sentence can also be joined by: conjunctive adverb such as furthermore, however, therefore, and otherwise. The punctuation of conjunctive adverb is special: use a semicolon after the first clause and a comma after the conjuctive adverb. A compound sentence can be formed with:

(ndependent clause; + conjunctive adverb, + Independent clause).

The independent clauses in a compound sentence may also be joined by a semicolon only. This kind of sentence occurs when the two independent clauses are closely related. If they weren't closely related, they would be written as two simple sentence, separate by a priod. The formula is : (independent clauses ;+ Independent clause)

\section{Complex Sentence}

A complex sentence contains one independent clause and at least one dependent clause. Unlike a compound sentence, however a complex sentence contains clauses which are not equal. Consider the following examples:

- Although my friend invited me to a party, I do not want to go

- Men who are not married are called bachelors

A complex sentence is very different from a simple sentence or a compound sentence because it makes clear which ideas are most important.

4. Compound - Complex Sentence 
A compound - complex sentence is a combination of two or more independent clauses and one or more dependent clauses. Example :

- After I graduated from high school, I wanted to travel, but I had to work in my family's business.

\section{Conclusion and Suggestion}

\subsection{Conclusion}

Teaching writing is highly complex activity for teacher to achieve the goal. It is because the students face some difficulties in writing activity. For the teacher, teaching writing is activity which is not only focuses on the grammatical form, also focuses on the process to guide the students to express and develop students' ideas in arranging sentences. The processes are prewriting, planning, writing and revising drafts, and final writing. In addition, for the students, they should express themselves in practicing their ability by following the four stages of teaching writing. Syntax is the study of the principles and processes by which sentences are constructed in particular languages. In linguistics, the study of the rules that govern the ways in which words combine to form phrases, clauses, and sentences. Syntax is one of the major components of grammar. The arrangement of words in a sentence. In this article, the writer uses syntax to analyze the students' errors in writing ability, there are phrases, clauses, and sentences error.

\subsection{Suggestion}

Finally, this article give information or as the reference for the reader about error analysis in writing an English text. Besides, it can be used as an input for the reader who wants to observe or to analyze the same problem in teaching English. Also for English teacher, It is also important to analyze the students' works whether the students use structure or grammar correctly or not. By knowing the students' errors, the teacher will be able to know how far the students have understood the material and give motivation for the students to increase the students'writing ability, especially in writing phrase, clause, and sentence.

\section{REFERENCES}

Bryne, Donn. 1995. Teaching Writing Skill. New York: Longman.

Harmer, Jeremy. 2004. How to Teach English. England: Person Education Limited Longman.

Hornby, AS. 2003. Oxford Advanced Learner's Dictionary. New York: Oxford University Press. 
James, Carl. 1998. Errors in Language Learning and Use. New York: Longman.

Kurniati. 2002. Analysis of Syntactic Error in translation. Jakarta. Universitas Gunadarma (unpublished script)

Muntaha and Alimin. 2009. Mastering English Grammar. Ujung Pangkal: Palanta.

Oshima, Alice. 1991. Writing Academic English. USA: Addision-Wasley Publishing Company.
Setiyadi, Bambang. And Junaidi. 2007. Strategi Pembelajaran Bahasa Inggris. Jakarta: Universitas Terbuka.

Tarigan, H. G. 2008. Berbicara Sebagai Salah Satu Keterampilan Berbahasa. Bandung: Angkasa. 